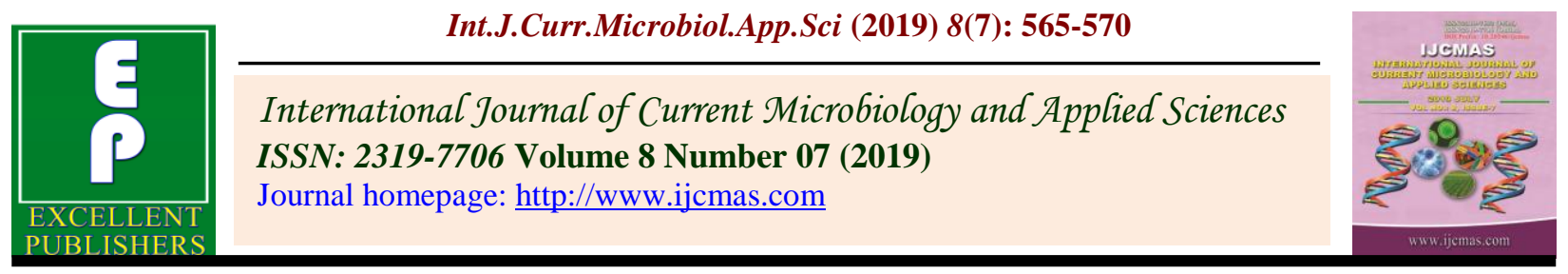

Original Research Article

https://doi.org/10.20546/ijcmas.2019.807.069

\title{
Adjustment Aspects of Old Age Persons in Hisar District (Haryana), India
}

\author{
M.K. Rathore ${ }^{1 *}$ and S. Sangwan ${ }^{2}$ \\ ${ }^{1}$ Department of Human Development and Family Studies, College of Home Science, \\ SKRAU, Bikaner, Rajasthan-334006, India \\ ${ }^{2}$ Department of Human Development and Family Studies, I.C. College of Home Science, \\ CCSHAU, Hisar, Haryana, India \\ *Corresponding author
}

\section{A B S T R A C T}

Keywords

Adjustment, Old age people, Health, Home, Social, Material, Emotional and financial

Article Info

Accepted:

07 June 2019

Available Online:

10 July 2019
Adjustment of the oldest old with the changing scenario and rising Platform of globalization, modernization and industrialization is very challenging and of utmost importance. This paper examines the level of adjustment in old age people and assesses the various socio-personal factors influencing it. The study was conducted in Hisar district of Haryana state from where urban area of Hisar was taken as locale of study. For this very purpose a sample of 30 old persons (>60 year) were selected purposively from old age people gathering in CCSHAU campus in evening hours. Respondents were assessed by using old age adjustment inventory (Hussain \& Kaur) to find out adjustment in the areas of health, home, social, material, emotional and financial aspects. The results revealed that majority of respondents were moderately adjusted followed by less than half of respondents, who were highly adjusted in the aspects of home, social and financial domains. Respondents' age had significant positive correlation whereas income had negative correlation with their marital adjustment aspect.

\section{Introduction}

Aging is unequivocally universal and irreversible process. This Process varies considerably within and between the genders. Aging is the part of biological, social, psychological and ecological factors. Old age is the last phase of the human life cycle. This life period, like any other, is of continuing change and adjustment both in the physical and the psychosocial realms.Critical gerontology, which has been rising for the last few decades, has been born as a necessary response especially to the scientific discourse which produces and reproduces the depressed and dependent status of old people. Old age is defined as age of retirement that is 60 years and above. Adjustment of the oldest old with 
the changing scenario and rising platform of globalization, modernization and industrialization is very challenging and of utmost importance. Improvement in health care technology has resulted in increased life expectancy. In India the elderly constitute about 7 per cent of the total population and by 2016 the number is likely to increase to 10 per cent. The problems of elderly are confined not only to their increasing numbers, but also include mental stress and physical incapability, felt by them. The scenario is changing and creating its impact on elderly. According to National Sample Survey Organization, 36.7 per cent of 70 Million elderly want to shift in old homes because they can't manage alone. Saraswati (1976) concluded in his study that the old age has started emerging as the social problem in Indian Society due to the socio-cultural changes brought about by Indus trial revolution. Several studies reported that a large number of old men and women badly need health care, financial assistance, social recognition and counseling services to cope up with stress for overcoming 'death anxiety', 'sense of isolation', feeling of social deprivation due to negligence, "feeling of disability and dependency", "low social esteem and lethargic feelings" (Dutta 1989, Saha 1984, Ananthraman 1982, Agnihotri 1976, Rammurti 1962).

A shift in the family paradigm has brought about a tremendous change in outlook, life style and the adjustment that the aged should make. Many factors such as marital status, finances, health, and family size Influence the adjustment of the oldest old. Despite these concerns, the success of adjustment of the oldest old largely depends on the quality of relationship being shared by both the generations effectively and emphatically. Parents and children need to respect each other's dignity and autonomy and accept their differences. Adjustment of the oldest old is of vital importance in the age of industrial advancement, globalization and era of modernization of the changing norms. Hence an attempt has been made in the present Study to know the level of adjustment made by the old age people and to delineate the factors influencing their adjustment level.

\section{Materials and Methods}

The present study was conducted in Hisar city of Haryana state. Urban area of Hisar was taken purposively as locale of study. This study was carried out to find out adjustment level of aged persons. For this very purpose a sample of 30 old persons (>60 year) were selected purposively from old age gathering in CCSHAU campus in evening hours. Adjustment aspects of old age people as dependent variable and socio-personal variables (age, education qualification, occupation, income, type of family, and status of partner) were taken as independent variable for the present study. The old age adjustment inventory developed by Hussain and Kaur (1995) was administered to find out adjustment level in areas -health adjustment, home adjustment, social adjustment, material adjustment, emotional adjustment and financial adjustment. For obtaining the information regarding personal profile, respondents were interviewed by using interview schedule. Frequency, percentage and Coefficient of correlation ( $r$ ) were used to analyze the data.

\section{Results and Discussion}

The data were collected in accordance with the research methodology to achieve the specific objectives of the study.

The data in Table 1 revealed that half (50\%)of the respondents were between 61-68 years of age, followed by age group 69-76 years and $77-85$ years with $(36.66 \%$ and $13.33 \%)$ 
respectively from the total sample. Regarding the education qualification of old age respondents the result highlighted that more than fifty per cent $(63.33 \%)$ of the total sample was qualified up to high school followed by the respondent's qualification up to post graduation and illiterate.

As far as occupation is concerned sample represented highest percentage $(70 \%)$ of respondents had service, followed by $26.66 \%$ and $3.33 \%$ respondents were in farming and business respectively. Results further revealed that $46.66 \%$ of respondents were having their income in range of Rs. 2,50,000-3,60,000 followed by $33.33 \%$ and $20 \%$ in range of Rs. 30,000-1,39,999 and Rs. 1,40,000-2,49,999 respectively. Regarding type of family the data indicated that 96.66 per cent of respondents' belonged to joint family in contrast to only 3.33 per cent of respondents belonged to nuclear family. Results also showed that 76.66 percent of respondents were having their alive partner.

Table.1 Frequency distribution of Socio- Personal profile of old age persons

\begin{tabular}{|c|c|c|}
\hline $\begin{array}{l}\text { Sr. } \\
\text { No. }\end{array}$ & Variable & Frequency $(\%)$ \\
\hline 1. & $\begin{array}{l}\operatorname{Age}(\mathbf{y r} .) \\
61-68 \\
69-76 \\
77-85\end{array}$ & $\begin{array}{l}15(50.00) \\
11(36.66) \\
4(13.33)\end{array}$ \\
\hline 2. & $\begin{array}{l}\text { Education qualification } \\
\text { Illiterate } \\
\text { Up to high school } \\
\text { Up to post graduation }\end{array}$ & $\begin{array}{l}1(3.33) \\
19(63.33) \\
10(33.33)\end{array}$ \\
\hline 3. & $\begin{array}{l}\text { Occupation } \\
\text { Farming } \\
\text { Service } \\
\text { Business }\end{array}$ & $\begin{array}{l}8(26.66) \\
21(70.00) \\
1(3.33)\end{array}$ \\
\hline 4. & $\begin{array}{l}\text { Income } \\
30,000-1,39,999 \\
1,40,000-2,49,999 \\
2,50,000-3,60,000\end{array}$ & $\begin{array}{l}10(33.33) \\
6(20.00) \\
14(46.66)\end{array}$ \\
\hline 5. & $\begin{array}{l}\text { Type of family } \\
\text { Nuclear } \\
\text { Joint }\end{array}$ & $\begin{array}{l}1(3.33) \\
29(96.66)\end{array}$ \\
\hline 6. & $\begin{array}{l}\text { Status of partner } \\
\text { Alive } \\
\text { Not alive }\end{array}$ & $\begin{array}{l}23(76.66) \\
7(23.33)\end{array}$ \\
\hline
\end{tabular}

Figures in parentheses indicate percentage 
Table.2 Frequency distribution of adjustment aspects of old age persons

\begin{tabular}{|l|l|l|l|}
\hline $\begin{array}{l}\text { Sr. } \\
\text { No. }\end{array}$ & Adjustment aspects & \multicolumn{2}{|c|}{ Level of adjustment } \\
\cline { 3 - 4 } & & $\begin{array}{l}\text { Moderate } \\
\text { f }(\%)\end{array}$ & $\begin{array}{l}\text { High } \\
\text { f }(\%)\end{array}$ \\
\hline 1. & Health & $24(80.00)$ & $6(20.00)$ \\
\hline 2. & Home & $14(46.66)$ & $16(53.33)$ \\
\hline 3. & Social & $21(70.00)$ & $9(30.00)$ \\
\hline 4. & Marital & $12(40.00)$ & $18(60.00)$ \\
\hline 5. & Emotional & $9(30.00)$ & $21(70.00)$ \\
\hline 6. & Financial & $23(76.66)$ & $7(23.33)$ \\
\hline 7. & Total & $19(63.33)$ & $11(36.66)$ \\
\hline
\end{tabular}

*Figures in parentheses indicate percentage

Table.3 Correlation between old age person's adjustment aspects and socio-personal variables (age and income)

\begin{tabular}{|l|l|l|l|l|l|l|l|l|l|}
\hline & Age & Income & Emotional & Financial & Health & Home & Marital & Social & $\begin{array}{l}\text { Total } \\
\text { adjustment }\end{array}$ \\
\hline Age & - & -.360 & .156 & -.200 & -.032 & .111 & $.439^{*}$ & -.047 & .158 \\
\hline Income & -.360 & - & -.101 & .198 & .124 & -.174 & $-.486^{*}$ & .007 & -.152 \\
\hline Emotional & .156 & -.101 & - & .205 & $.453^{*}$ & .016 & .315 & $.633^{*}$ & $.746^{*}$ \\
\hline Financial & -.200 & .198 & .205 & - & $.485^{*}$ & $.570^{*}$ & -.191 & $.484^{*}$ & $.586^{*}$ \\
\hline Health & -.032 & .124 & $.453^{*}$ & $.485^{*}$ & - & $.496^{*}$ & -.039 & $.540^{*}$ & $.749^{*}$ \\
\hline Home & .111 & -.174 & .016 & $.570^{*}$ & $.496^{*}$ & - & -.066 & $.384^{*}$ & $.565^{*}$ \\
\hline Marital & $.439^{*}$ & $-.486^{*}$ & .315 & -.191 & -.039 & -.066 & - & .125 & $.371^{*}$ \\
\hline Social & -.047 & .007 & $.633^{*}$ & $.484^{*}$ & $.540^{*}$ & $.384^{*}$ & .125 & - & $.805^{*}$ \\
\hline $\begin{array}{l}\text { Total } \\
\text { adjustment }\end{array}$ & .158 & -.152 & $.746^{*}$ & $.586^{*}$ & $.749^{*}$ & $.565^{*}$ & $.371^{*}$ & $.805^{*}$ & - \\
\hline
\end{tabular}

*Correlation is significant at the 0.05 level (2-tailed)

The result in table 1 highlighted that majority $(80.00 \%)$ of the respondents were moderate in their health adjustment followed by a few $(20.00 \%)$ of respondents were high in their health adjustment. Regarding home aspect of adjustment, data in Table 2 showed that more than half $(53.33 \%)$ respondents were highly adjusted followed by moderately adjusted (46.66\%). Majority of the respondents (70.00\%) had moderate level of adjustment; remained 30 per cent of respondents had high level of adjustment regarding social aspect. Further 60 per cent respondents were highly adjusted nevertheless 40 per cent of respondents in moderately adjusted regarding marital aspect. Results further showed that majority of respondents were highly adjusted (70.00\%) followed by moderately adjusted $(30.00 \%)$ regarding emotional aspect and moderately adjusted respondents were having greater strength $(76.66 \%)$ followed by highly adjusted $(23.33 \%)$ respondents regarding financial aspect of adjustment. As a whole total perspective of adjustment revealed that 63.33 per cent of respondents were moderately adjusted followed by 36.66 per cent of respondents, who were highly adjusted. There were no any individual who 
had low level of adjustment as a whole or with reference to any of the individual adjustment aspect.

Data compiled in table 3 unveils the correlation between the adjustment aspects and socio-personal variables (age and income) of the respondents. It is evident from table 3 that respondents' age had significant positive correlation with of the respondents' marital adjustment $(\mathrm{r}=0.439 *)$. There was a clear existence of significant positive correlation of emotional adjustment aspect with health, social and total adjustment aspects of respondents with $\left(\mathrm{r}=0.453 *, 0.633^{*}\right.$ and $\left.0.746^{*}\right)$ respectively. Financial adjustment aspect was also positively significantly correlated with health, home, social and total adjustment aspects having $\left(\mathrm{r}=0.485^{*}, 0.570^{*}\right.$, $0.484 *$ and $0.586 *$ ) respectively.

Health aspect of adjustment of respondent's also had significant positive relation with emotional $\left(0.453^{*}\right)$, financial $\left(\mathrm{r}=0.485^{*}\right)$, home $\left(0.496^{*}\right)$, social $\left(\mathrm{r}=0.540^{*}\right)$ and total adjustment $\left(\mathrm{r}=0.749^{*}\right)$. Old age person's home adjustment aspect had significant positive relation with financial $\left(\mathrm{r}=0.570^{*}\right)$, health $\left(\mathrm{r}=0.496^{*}\right)$, social $\left(\mathrm{r}=0.384^{*}\right)$ and total adjustment level $(\mathrm{r}=0.565)$. It is clear from data that the income of respondents' was negatively correlated with their marital adjustment aspect $\left(\mathrm{r}=-0.486^{*}\right)$. Data disclosed a significant positive correlation of marital adjustment with total adjustment level $\left(\mathrm{r}=0.371^{*}\right)$ of old aged respondents. Data further revealed existence of significant positive correlation between social adjustment and emotional adjustment $\left(\mathrm{r}=633^{*}\right)$, financial $\left(\mathrm{r}=0.484^{*}\right)$, health $\left(\mathrm{r}=0.540^{*}\right)$, home $\left(\mathrm{r}=0.384^{*}\right)$ and total adjustment $\left(\mathrm{r}=0.805^{*}\right)$. Total adjustment aspect of old age person's was positively correlated with emotional $\left(\mathrm{r}=0.746^{*}\right)$, financial $\left(\mathrm{r}=0.586^{*}\right)$, health $\left(\mathrm{r}=0.749^{*}\right), \quad$ home $\left(\mathrm{r}=0.565^{*}\right)$, marital $\left(\mathrm{r}=0.371^{*}\right)$ and social adjustment $\left(\mathrm{r}=0.805^{*}\right)$.
As the result of the present study revealed that better level of total adjustment perspective among old age can be characterized by no problems in emotional, financial, health, home, marital and social aspect of living their life. This can be supported indirectly by Braithwaite and Braithwaite and Gibson (1987) who studied the adjustment to retirement period and concluded those poor adjusters are more likely to have health problems, inadequate income and to be more negatively disposed to retirement. Work commitment and job satisfaction do not appear to be linearly related to retirement adjustment and adjustment improved with time but rates differ according to retirement circumstances. Likewise health and social adjustment in post-retirement phase possess Emotional, financial, home and total wellbeing. This may be due to achieving physiological safety with good health and social company for psychological betterment for an individual. In a study conducted by Age well Research \& Advocacy Centre (2010), who's finding focuses that older persons no longer want to be marginalized from society or family. They want to remain in the mainstream of the society as they were before their Retirement i.e. before their 60's. They seemed to be desperate to remain in center Stage and never ready to accept corner of the house or being isolated by Family/society members. They understand that due to old age and changed socioeconomic scenario, their needs have also changed and they cannot depend on others to address their changed needs. Older Persons thought that they have enough knowledge, experience and Capabilities to change things for the betterment of their life in Old Age.

\section{References}

Agewell Research \& Advocacy Centre. 2010. Isolation in Old Age - A National Study. Age Well Study. PP: 1-21. 
Agewell Foundation. M-8A, Lajpat Nagar-II, New Delhi

Agnihotri, H.K. 1976. Problems of the Old Age. Journal of Psychological researches. $22,1$.

Ananthraman R.N. 1983. Concepting Self among Elderly. Indian Psychological abstracts No. 304, 20, 2, PP 47-51.

Braithwaite, V. A. and Gibson, D. M. 1987. Adjustment to Retirement: What We Know and What We Need To Know. Ageing and Society. 7: 1-18

Dutta, E. 1989. Growing Old in Young India. Sunday review -The times of India Sept. 17
Hussain, S. and Kaur, J. 1995. ShamshadJasbir Old-Age Adjustment Inventory (SJOAI). National psychological corporation. Agra

Note: Paper was presented at $1^{\text {st }}$ international and $3^{\text {rd }}$ Indian psychological science congress, Chandigarh on $24^{\text {th }}-25^{\text {th }}$ February, 2014. National association of psychological science- India.

Ram Murti, P.V. 1962. An adjustment Inventory for older people. Journal of psychological researches. VII (3)

Saraswati, H. 1976. The changing relationships between young and the old Journal Social welfare, 24, 29-32

\section{How to cite this article:}

Rathore, M.K. and Sangwan, S. 2019. Adjustment Aspects of Old Age Persons in Hisar District (Haryana), India. Int.J.Curr.Microbiol.App.Sci. 8(07): 565-570. doi: https://doi.org/10.20546/ijcmas.2019.807.069 